- Alumni relations. Tracking and engaging IBC alumni is acknowledged as a key dimension of long-term success, but is typically at a nascent stage.

\section{Student EXPERIENCE}

- Student body: IBC leaders perceive their students to be international or internationally minded, with an openness to new models of education. IBCs tend to enroll large numbers of international as well as domestic students, depending on the host country.

- Relative replication: Institutions insist on consistent academic standards and practices between the home campus and all IBCs. Other areas (student experience, program offerings, fee structures, staffing models, etc.) may be more diverse, in line with local needs and norms.

- Student mobility: While student mobility between institutional sites is usually a pillar of IBC strategy, it is not always as active as desired and is often skewed in one direction.

- Online delivery: There is potential to use online technologies to link students and academic programs between locations, but this is a minor component of current delivery models.

The full report-90 pages in length-offers considerably more detail about the eight mature IBCs studied, including quotes from the interviews with institutional and campus leaders. Both parts of the IBC report are free to Observatory members and available for purchase to nonmembers. Please contact info@obhe.org for login details or to purchase the report.

DOI: http://dx.doi.org/ıo.6oI7/ihe.20I8.93.I0374

\section{Student Debt in the United States: Rhetoric vs Reality}

\section{SANDY BAUM}

Sandy Baum is a fellow at the Urban Institute, Washington, DC, US. E-mail: sbaum@urban.org.

$\mathrm{T}$ The idea of student debt "crushing a generation" pervades discussions of higher education in the United States. Anecdotes about former students struggling with large amounts of debt and low earnings get a lot of press coverage, and political candidates vow to make college "debt free." There are, in fact, significant systemic problems in the higher education system, but most of the stories garnering attention are atypical. The real crisis is obscured by calls for easing the burdens on young college graduates, who are, in fact, among the groups with the most promising life prospects.

Because of the association between higher levels of education and higher incomes, education debt holders tend to be relatively well off. In 2013 , the 25 percent of households with the highest incomes held almost half of all outstanding student debt. The 25 percent of households with the lowest incomes held II percent of the debt. The people who are having the most trouble making ends meet are those who have not gone to college and may not even have graduated from high school. Some student loan borrowers face very real problems that public policy should address. But some proposals for general student debt relief would provide the largest benefits to individuals with relatively high earnings.

\section{The idea of student debt "crushing a generation" pervades discussions of higher education in the United States.}

\section{Basic Facts about Student Debt}

The press finds individual students with staggering amounts of debt and few job prospects, but two-thirds of borrowers with outstanding student loan debt owe less than \$25,000. Only 5 percent owe as much as \$I00,000. Two-thirds of the students graduating with $\$ 50,000$ or more in debt, and 94 percent of those with $\$$ IO०, 000 or more in debt, have graduate degrees. The average debt of 2015-2016 bachelor's degree recipients at public and private nonprofit colleges and universities who took student loans was $\$ 28,400$; about 40 percent did not borrow at all. In light of the fact that median earnings for 25-to-34-year olds with bachelor's degrees were \$I8,900 higher than the median for those with only a high school diploma in 2015, this is not a daunting amount.

Debt levels have, however, grown rapidly. Between 2003-2004 and 20II-20I2, the share of bachelor's degree recipients in the United States who had borrowed $\$ 40,000$ (in 2012 dollars) or more rose from 2 percent to I8 percent, rising from I percent to I2 percent at public colleges and universities (which award almost two-thirds of all bachelor's degrees) and from 4 percent to 48 percent in the for-profit sector (which awarded 8 percent of bachelor's degrees in 20II-20I2). 
Talk about a "student debt crisis" fails to differentiate among groups of students. For example, only iI percent of students who completed bachelor's degrees in 2OII-2OI2 when they were age 23 or younger had borrowed as much as $\$ 40,000$, but about 30 percent of those who completed their degrees at age 30 or older had accumulated this much debt. Black bachelor's degree recipients are much less likely to graduate without debt and much more likely than members of other racial/ethnic groups to borrow $\$ 40,000$ or more. Contributing factors likely include lower income and wealth among black families, longer time to degree, and disproportionate enrollment in for-profit institutions among black students.

\section{When Borrowers Do Not Repay Their Debts}

The federal income-driven student loan repayment options, in which a quarter of all borrowers now participate, limit monthly payments to affordable amounts. But, unlike students in some other countries, US students have to overcome considerable bureaucratic hurdles to enroll in these programs and many borrowers still default.

Default rates are highest for those with the lowest levels of debt; two-thirds of defaulters enter repayment owing $\$$ Io,००0 or less. Default rates are two to three times as high among borrowers who did not complete a degree or certificate as among those who graduated. They are much higher among students who borrowed to attend for-profit and twoyear public institutions than among students from fouryear public and private nonprofit colleges and universities. Again, it is not the traditional college students frequently making the front page of the newspaper, but the nontraditional students-older, independent students seeking occupational preparation-who are most likely to encounter repayment problems.

\section{Promising Solutions}

The alarmist narrative about student debt distracts from serious problems that could be addressed without totally transforming the system of higher education finance, or arbitrarily and disproportionately shifting burdens from the people who benefit most from higher education to taxpayers in general. Too many students borrow to enroll in colleges and programs from which they are unlikely to graduate and/or which, even if they do graduate, are not likely to lead to positive labor market outcomes. The recent recession exacerbated these problems. Many adults who could not find jobs went back to school, frequently to expensive for-profit institutions. Public college prices rose rapidly and families were less able to support students. And students who completed college entered the labor force while the economy was weak and unemployment was high.
Some well-targeted policy options would be fairer and more efficient than broad debt-relief policies. US students need stronger precollege academic preparation, better guidance about choosing schools and programs, better policing of postsecondary quality, and better student support systems. The United States needs stricter rules for institutional eligibility for federal student aid programs and stronger incentives for institutions to improve performance and reduce student debt levels. We should limit borrowing through lower loan limits for part-time students and by tracking students across institutions so they do not accumulate more and more debt without any progress toward a credential. And we should stop allowing graduate students and parents of undergraduates to borrow to cover all of their expenses no matter how high those costs.

The United States needs a single income-driven repayment plan into which borrowers would be placed automatically and through which payments would be withheld from paychecks, along the lines of systems that already exist in a number of other countries. Forgiving unpaid balances after a set period of time is reasonable, but terms should be set so most borrowers repay their entire balances. Total payments should bear some relationship to the amount borrowed and there should be limits on the amount of debt that can be forgiven.

\section{CONCLUSION}

Student debt is seriously harming too many former students. But federal extension of credit to undergraduate students makes it possible for many individuals, particularly those with limited financial means, to pursue postsecondary studies, enroll into an appropriate college, and succeed. Some policies to alleviate debt burdens that sound progressive can actually skew subsidies away from those who need them most.

The borrowers who are struggling most with student debt are those who borrowed relatively small amounts but did not earn credentials of value in the labor market. Forgiving debt across the board or even lowering interest rates on that debt will provide the largest benefit to people who do not really need the help. No one should borrow money to go to a postsecondary institution with an abysmal graduation rate or poor job outcomes for those who do graduate-no one should put time and effort into such an institution even if it does not require borrowing. This does not mean that all borrowing for college is bad. It just has to be cautious and well informed.

Producing high quality education opportunities requires significant resources. Someone has to pay. Students are and should be responsible for a portion of that funding. Acknowledging that reality, and working to develop a 
system that both prepares and protects people seeking to invest in themselves through postsecondary education, should be high on the national policy agenda.

DOI: http://dx.doi.org/ıo.6oI7/ihe.20I8.93.1038I

\section{Income-Contingent Loans: Not a Miracle Solution}

\section{Ariane de Gayardon}

Ariane de Gayardon is researcher at the Institute of Education Centre for Global Higher Education, University College London, UK. E-mail: a.gayardon@ucl.ac.uk.

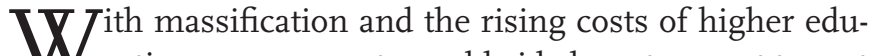
cation, governments worldwide have to resort to cost sharing to alleviate the weight of higher education funding on the state. With the rise of tuition fees, however, governments have to structure financing options ensuring that students from all walks of life have the opportunity to access higher education. This has led to the creation of government-guaranteed student loans.

While individuals are able to take up loans from private banks to finance different products like homes and cars, higher education is rarely one of them. Investing in students is indeed a risky investment for banks given high noncompletion rates and the impossibility of taking back the product invested in-like taking possession of a home when a mortgage is no longer being repaid. For these reasons, governments have to be heavily involved in the provision of student loans.

\section{InCOME-CONTINGENT LOANS}

Government loans for education usually take one of two forms: a mortgage-style loan or an income-contingent loan (ICL). In the case of a mortgage-style loan, the individual has to repay the total amount of his/her loan plus interest during a set period of time, leading to mandatory fixed monthly payments. The main disadvantage of this type of loan is that higher education is no guarantee that one will have the means to repay-these loans can lead to repayment hardship, default, and subsequently credit reputation loss.

ICLs are designed to propose a fairer option for students. Repayment of the loans is tied to income, with individuals repaying a share of their income, usually for a fixed amount of time. This insures against high repayment burdens. It also eliminates default, as governments automatically forgive outstanding balances once the payment period is over: this is called the "hidden grant." For these reasons, ICLs have many advocates across the world: they are seen as a way to provide free higher education at the point of entry and ensure a smooth and equitable repayment.

\section{What Is Currently Happening?}

In 2017 , however, there were increasingly heightened debates on the financing of higher education in three flagship countries for ICLs: Australia, England, and New Zealand. Examining the relevant issues and learning from them is important at a time when student debt is rising, leading to a revival of the concept of free-tuition higher education.

Australia is at a political standstill over higher education financing because of the balance of power in the senate, which has been unable to pass any legislation on higher education financing since 20I3. Failed legislative proposals in recent years include fees deregulation, reducing the income repayment threshold, and introducing a student loan fee. These proposals all aimed at reducing the expenses of the Higher Education Loan Program (HELP) to ensure its sustainability. In December 20I7, the government took a radical measure by including higher education financing

\section{What the examples of these three coun- tries show us is that systems with ICLs are also prone to issues and question- able policy decisions.}

reforms in the 2018 budget. The reforms lowered the repayment threshold by AU\$ II, O०० (US\$9,000), which will negatively impact individuals with lower incomes, and froze university budgets for two years, reducing institutional ability to fund students. The decision of the Australian government to pass these changes as part of the budget is a direct testimony of its inability to sustain the current system.

England has also been overwhelmed by debates on higher education financing since the Labour Party regained popularity thanks to a proposal to make higher education tuition free, a sign of the general discontent with the high cost of higher education and increasing levels of student loan debt. Among the issues under discussion in England: the fact that the financial protection afforded by ICLs has led to an inflation of the cap on tuition fees, from $£$ I, , ० (US\$1,400) means-tested in I998 to $£$ 9,250 (US\$13,000) for all in 20I7. The high rate of interest (up to 3 percent plus inflation) that is in effect during the student's course of study also contributes to increased debt levels and angry loan recipients. Additionally, as of 2016 , grants have completely disappeared and been replaced by loans-a financial move to reduce the national deficit. As a result, low-income 